\title{
FENOMENA MIGRASI TENAGA KERJA DAN PERANNYA BAGI PEMBANGUNAN DAERAH ASAL: STUDI EMPIRIS DI KABUPATEN WONOGIRI
}

\author{
Didit Purnomo \\ Fakultas Ekonomi Universitas Muhammadiyah Surakarta \\ E-mail: didiet_p@yahoo.com
}

\begin{abstract}
This research analyzes (a) patterns of labor migration from Wonogiri Regency, (b) the impact of migration on the welfare level by taking into account the income level of migrant Wonogiri Regency, and (c) the role of migrants seen from homelands conditions. The results of binary logistic analysis showed that the variables age, education, and marital status, have a significant effect on intention nomads to settle in the overseas area. Based on survey findings in the field, 88.8 percent of Wonogiri nomads do not want to settle in the overseas regions. The economic analysis through linear regression analysis to explain the role of the nomads and the impact on the regional origin that shows only one independent variable that is used has a significant influence on the local nomads income overseas, namely: level of education, while the other independent variables are family dependents, ownership of property in the area of origin, length of stay in overseas, and marital status had no significant effect.
\end{abstract}

Keywords: binary logistic, linier regression, perantau/migran, boro

\section{PENDAHULUAN}

Perpindahan penduduk dari daerah pedesaan ke daerah perkotaan menjadi salah satu bagian dari proses pembangunan. Aktivitas perpindahan penduduk dari desa ke kota hanya merupakan salah satu penyebab proses urbanisasi, di samping penyebab-penyebab lain seperti pertumbuhan alamiah penduduk perkotaan, perluasan wilayah, maupun perubahan status wilayah dari daerah pedesaan menjadi daerah perkotaan. Proses urbanisasi di Indonesia diperkirakanakan lebih banyak disebabkan migrasi desa-kota, yang didasarkan pada makin rendahnya pertumbuhan alamiah penduduk di daerah perkotaan, relatif lambannya perubahan status dari daerah pedesaan menjadi daerah perkotaan, serta relatif kuatnya kebijaksanaan ekonomi dan pembangunan yang "urban bias", sehingga memperbesar daya tarik daerah perkotaan bagi penduduk yang tinggal di daerah pedesaan (Prijono, 2000).

Fenomena migrasi sangat mewarnai di beberapa negara berkembang, termasuk di berbagai daerah di Indonesia, terutama dalam konteks, dimana banyak tenaga kerja yang berasal dari daerah pedesaan mengalir ke daerah perkotaan. Proses migrasi yang berlangsung dalam suatu negara (internal migration) dianggap sebagai proses alamiah 
yang akan menyalurkan surplus tenaga kerja di daerah-daerah ke sektor industri modern di kota-kota yang daya serapnya lebih tinggi, walaupun pada kenyataannya arus perpindahan tenaga kerja dari daerah pedesaan ke perkotaan tersebut telah melampaui tingkat penciptaan lapangan kerja, sehingga migrasi yang terjadi jauh melampaui daya serap sektor industri dan jasa di daerah perkotaan (Todaro, 1998).

Mantra (1992) juga menjelaskan bahwa motivasi utama orang melakukan perpindahan dari daerahnya (pedesaan) ke perkotaan adalah motif ekonomi. Motif tersebut berkembang karena adanya ketimpangan ekonomi antardaerah. Kondisi yang paling dirasakan menjadi pertimbangan rasional, dimana individu melakukan mobilitas ke kota adalah adanya harapan untuk memperoleh pekerjaan dan memperoleh pendapatan yang lebih tinggi daripada yang diperoleh di desa. Senada dengan hal di atas, Robert dan Smith (1977) juga memberikan penjelasan seperti dikutip oleh Hossain (2001) bahwa tidak meratanya pekerjaan dan penghasilan pertanian di pedesaan menjadi motivasi migrasi desa-kota. Motivasi tersebut senada dengan model migrasi Todaro (Todaro, 1992; 1998) yang melandaskan pada asumsi bahwa migrasi dari desa ke kota pada dasarnya merupakan suatu fenomena ekonomi, dimana terdapat perbedaan penghasilan yang diharapkan daripada penghasilan aktual antara desa-kota.

Kondisi sosial-ekonomi di daerah asal yang tidak memungkinkan untuk memenuhi kebutuhan seseorang menyebabkan orang tersebut ingin pergi ke daerah lain yang dapat memenuhi kebutuhan tersebut. Sedangkan tiap individu mempunyai kebutuhan yang berbeda, maka penilaian terhadap daerah asal dari masing-masing individu di masyarakat tersebut berbeda-beda, sehingga proses pengambilan keputusan untuk pindah (mobilitas) dari masing-masing individu berbeda pula (Mantra, 1992).

Fenomena migrasi yang berlangsung dalam suatu negara (internal migration) banyak terlihat di berbagai wilayah Indonesia (interprovincial) (Prasetyo, 1995; Tommy, 1994). Salah satu daerah yang mencerminkan adanya fenomena migrasi antar daerah (interprovincial migration) diperlihatkan oleh tenaga kerja asal Wonogiri. Kabupaten Wonogiri merupakan salah satu Jawa Tengah di Indonesia yang mempunyai banyak tenaga kerja yang melakukan mobilitas (boro) ke luar daerah. Lebih kurang 121 ribu penduduk Kabupaten Wonogiri (dari masing-masing kecamatan) yang melakukan aktivitas tersebut (Dinas Kependudukan dan Catatan Sipil, Bappeda Kab. Wonogiri tahun 2006).

Dibandingkan dengan total jumlah penduduk kabupaten Wonogiri yang berjumlah 1.127.907 (Dinas Kependudukan, 2006), jumlah penduduk yang melakukan mobilitas ke luar daerah (boro) lebih kurang 10 persennya. Hal ini menunjukkan bahwa Wonogiri merupakan daerah yang potensial sebagai asal migran. Selain itu kondisi lahan pertanian yang kurang subur juga termasuk faktor mendorong mereka untuk merantau walaupun hal ini bukan menjadi faktor utama Secara tidak langsung, kondisi di atas dapat menjelaskan permasalahan yang dihadapi oleh tenaga kerja asal Wonogiri. Kenyataan inilah yang kemudian tercermin dalam fenomena mobilitas tenaga kerja Wonogiri ke luar daerah ('boro'), terutama ke kota-kota besar yang dianggap memberikan harapan pendapatan yang lebih baik. 
Penelitian ini dimaksudkan untuk mencoba melanjutkan penelitian terdahulu yang meneliti tentang migrasi penduduk dengan subyek penelitian di daerah Kabupaten Wonogiri. Dalam penelitian terdahulu disimpulkan bahwa pola migrasi penduduk (para migran) di Wonogiri dengan tujuan Jakarta cenderung bersifat sirkuler, yaitu mereka lebih suka tidak menetap secara permanen. Pada rencana penelitian yang kami ajukan dalam hibah pekerti ini, akan dikembangkan pada daerah tujuan migran, yaitu beberapa kota tujuan migran selain Jakarta. Hal ini dimaksudkan untuk menjelaskan kondisi migran yaitu dengan cara membandingkan keniatan dan pola migrasi para migran asal Wonogiri, sekaligus untuk membandingkan remitance yang dihasilkan sebagai cerminan atas peran mereka melakukan aktivitas 'boro'. Obyek penelitian difokuskan pada daerah 'kantong migran', yaitu daerah (kecamatan/desa) yang banyak perantau. Responden yang kami sampel adalah mereka yang melakukan aktivitas 'boro' dan bekerja di luar daerah Wonogiri, baik di beberapa kota di Jawa maupun di luar Jawa.

Berdasarkan penelitian terdahulu, para migran (tenaga kerja yang boro dan bekerja di luar daerah Wonogiri) lebih bersifat 'sirkuler', yaitu lebih cenderung tidak menetap atau tidak permanen. Fenomena yang kami tangkap adalah di antara mereka yang boro tersebut, ada yang tidak mempunyai keterampilan apapun, jadi hanya sekedar diajak teman atau berdasar pengalaman 'seniornya'.

Berdasarkan berbagai potensi dan masalah sebagaimana tinjauan di atas, permasalahan yang diangkat dalam penelitian ini adalah (a) bagaimana pola migrasi tenaga kerja (migran) asal daerah penelitian? (b) bagaimana dampak migrasi yang dilakukan oleh para migran terhadap tingkat kesejahteraan (welfare) di daerah asal.

\section{Teori Migrasi}

Berkenaan dengan kajian ekonomi migrasi internal, Todaro (1992) menjelaskan teori migrasi yang diformulasikan oleh Lewis (1954), yaitu tentang proses perpindahan tenaga kerja desa-kota, dimana model yang dikembangkan Lewis pada tahun 1954 tersebut diperluas Fei dan Ranis pada tahun 1961 dan merupakan teori umum yang diterima dan dikenal dengan Model LewisFei-Ranis (L-F-R).

Peribahasa "ada gula ada semut" menjelaskan kondisi paling cocok dengan adanya fenomena proses migrasi desa-kota. Para migran nonpermanen (sirkuler) berperilaku seperti semut, maksudnya bila semut menemukan makanan di suatu tempat, makanan itu tidak dimakan di tempat itu, tetapi dibawa bersama teman-temannya ke sarangnya (Ida Bagoes, 2000).

Menurut Oishi (2002) adalah mengenai Network theory, yang mengkaitkan proses migrasi melalui hubungan personal, kultur, dan hubungan-hubungan sosial lain. Oishi (2002) menjelaskan bahwa di negara-negara pengirim migran, informasi tentang pekerjaan dan standar hidup di luar negeri secara efisien disampaikan melalui jaringan personal seperti teman dan tetangga yang telah beremigrasi. Sedangkan di negara-negara penerima (negara tujuan), masyarakat migran sering membantu laki-laki dan wanita seusianya (sejawat) untuk berimigrasi, mendapatkan suatu pekerjaan, dan menyesuaikan dengan suatu lingkungan baru. Jaringan yang demikian ini mengurangi biaya-biaya migrasi bagi para pendatang baru, yang menyebab- 
kan para migran yang potensial untuk meninggalkan negara (daerah) mereka.

\section{Bentuk-bentuk Mobilitas Penduduk}

Oleh Mantra (2000) dijelaskan bahwa mobilitas penduduk dapat dibedakan menjadi dua, yaitu pertama, mobilitas penduduk vertikal, yang sering disebut dengan perubahan status. Contohnya adalah perubahan status pekerjaan, dimana seseorang semula bekerja dalam sektor pertanian sekarang bekerja dalam sektor non-pertanian. Kedua, mobilitas penduduk horisontal, yaitu mobilitas penduduk geografis, yang merupakan gerak (movement) penduduk yang melewati batas wilayah menuju wilayah lain dalam periode waktu tertentu.

Selanjutnya Mantra (2000) menjelaskan bila dilihat dari ada tidaknya niatan untuk menetap di daerah tujuan, mobilitas penduduk dapat pula dibagi menjadi dua, yaitu mobilitas penduduk permanen atau migrasi; dan mobilitas penduduk non-permanen. Jadi, menurut Mantra (2000) migrasi adalah gerak penduduk yang melintas batas wilayah asal menuju ke wilayah tujuan dengan niatan menetap. Sebaliknya, mobilitas penduduk non-permanen adalah gerak penduduk dari suatu wilayah ke wilayah lain dengan tidak ada niatan menetap di daerah tujuan.
Sedangkan menurut Steele (1983), seperti dikutip Mantra (2000), bila seseorang menuju ke daerah lain dan sejak semula sudah bermaksud tidak menetap di daerah tujuan, orang tersebut digolongkan sebagai pelaku mobilitas non-permanen walaupun bertempat tinggal di daerah tujuan dalam jangka waktu lama.

Lebih lanjut menurut Mantra (2000), gerak penduduk yang non-permanen ( $\mathrm{circu}$ lation) ini juga dibagi menjadi dua, yaitu ulang-alik (Jawa $=$ nglaju; Inggris $=$ commut ing) dan menginap atau mondok di daerah tujuan. Mobilitas ulang-alik adalah gerak penduduk dari daerah asal menuju ke daerah tujuan dalam batas waktu tertentu dengan kembali ke daerah asal pada hari itu juga. Sedangkan mobilitas penduduk mondok atau menginap merupakan gerak penduduk yang meninggalkan daerah asal menuju ke daerah tujuan dengan batas waktu lebih dari satu hari, namun kurang dari enam bulan. Secara ringkas bentuk-bentuk mobilitas penduduk di atas diringkas dalam tabel 1.

\section{Pola Migrasi Desa - Kota}

Pola migrasi di negara-negara yang sudah berkembang pesat biasanya sangat kompleks. Fenomena ini menggambarkan kesempatan ekonomi yang lebih seimbang dan menun-

Tabel 1. Bentuk-bentuk Mobilitas Penduduk

\begin{tabular}{|c|c|c|}
\hline Bentuk Mobilitas & Batas Wilayah & Batas Waktu \\
\hline 1. Ulang-alik (commuting) & Dukuh (dusun) & $\begin{array}{l}6 \text { jam atau lebih dan kembali pada } \\
\text { hari yang sama }\end{array}$ \\
\hline 2. Menginap/mondok di daerah tujuan & Dukuh (dusun) & $\begin{array}{l}\text { Lebih dari satu hari tetapi kurang dari } \\
6 \text { bulan }\end{array}$ \\
\hline 3. Permanen/menetap di daerah tujuan & Dukuh (dusun) & $\begin{array}{l}6 \text { bulan atau lebih menetap di daerah } \\
\text { tujuan }\end{array}$ \\
\hline
\end{tabular}

Sumber: Ida Bagoes, 2000 
jukkan saling ketergantungan (interdependensi) antarwilayah di dalamnya, serta merefleksikan keseimbangan aliran sumberdaya manusia dari suatu wilayah ke wilayah lainnya. Sedangkan di negara-negara yang sedang berkembang, pola migrasi yang terjadi menunjukkan suatu pengutuban (polarisasi), yaitu pemusatan arus migrasi ke wilayah-wilayah tertentu saja, khususnya kota-kota besar (Tommy, 1994). Hal yang sama juga dijelaskan oleh Titus (1991) bahwa pola migrasi desa-kota di negara berkembang (termasuk di Indonesia) menunjukkan adanya konsentrasi pendatang yang tinggi di kota-kota besar seperti misalnya Jakarta, yaitu kota-kota yang relatif mempunyai sektor modern yang besar dan dinamis. Sedangkan kota-kota kecil lainnya yang kurang dinamis seringkali menunjukkan tingkat migrasi netto (selisih migrasi keluar dengan migrasi masuk) yang rendah. Dengan demikian dikemukakan oleh (Titus, 1991) bahwa migrasi desa-kota tidak hanya disebabkan oleh faktor dorongan di desa, tetapi juga oleh faktor daya tarik di kota. Berkenaan dengan hal tersebut, perpindahan (mobilitas) tenaga kerja desa-kota tidak selalu berpola pada pergerakan tenaga kerja dari daerah kecil (kecamatan/kabupaten) ke daerah besar (kota propinsi/ibu kota). Pola daerah tujuan tenaga kerja tersebut menurut Yang (1992) mempunyai empat kategori, yaitu: urban town, small city, medium-sized city dan big city.

\section{Penelitian Terdahulu}

Beberapa studi migrasi di Indonesia masih berorientasi pada migrasi internal yang diantaranya meliputi pola migrasi antara provinsi atau pulau, migrasi desa-kota dan urbanisasi, serta mobilitas yang nonperma- nen (Bandiono dan Alihar, 1999). Tommy (1994) juga mengungkapkan bahwa pola migrasi antarprovinsi dalam kurun waktu 1989-90 masih kelihatan "Jawa Sentris" karena sebagian besar migran berasal dari dan menuju ke provinsi-provinsi di Jawa, sehingga peran provinsi-provinsi di Jawa dalam hal migrasi antarprovinsi yang menuju perkotaan sangat dominan. Kondisi ini menggambarkan dominasi kegiatan ekonomi perkotaan, khususnya industri dan jasa di provinsi jawa. Diungkapkan pula oleh Prasetyo (1995) dalam studinya tentang migrasi antardaerah (interprovinsial), terutama Jawa dan luar Jawa, bahwa bila daerah di luar Jawa berkeinginan mengambil daya tarik lebih banyak orang-orang dari Jawa, seharusnya propinsi tersebut lebih dapat menyediakan fasilitas yang lebih baik dari pada tempat asal migran.

Hasil penelitian Ida Bagoes (1978); Penny dan Singarimbun (1973) seperti dikutip oleh Ida Bagoes (1992) menunjukkan bahwa sekitar 50 persen dari penduduk di daerah pedesaan di Jawa tidak memiliki lahan sawah. Kelangkaan lahan garapan di daerah asal inilah yang menurut Ida Bagoes (1992) menjadi salah satu penyebab terjadinya proses perpindahan penduduk desa-kota, terutama di daerah pedesaan di Jawa. Namun, menurut Ida Bagoes (1992) pula, daerah tujuan di kota juga merupakan harapan untuk mendapatkan pekerjaan dan pendapatan yang lebih besar. Sedangkan Kennan dan Walker (2002) menyatakan bahwa perbedaan lokasi atau daerah tujuan berpengaruh terhadap keputusan seseorang dalam bermigrasi, dimana lokasi atau daerah yang lebih besar (kota-kota besar) lebih menarik bagi mereka yang akan melakukan migrasi ke kota. 
Riset yang dilakukan oleh Zhao (1998), tentang keputusan bermigrasi dengan mengambil survei di provinsi Sichuan, China, menyimpulkan bahwa variabel umur, pendidikan, jumlah anak yang belum sekolah, jumlah anak yang sekolah, luas lahan di desa, variabel besarnya pajak yang harus dibayar migran dalam setahun, sarana jalan aspal yang menghubungkan desa-kota, serta adanya fasiltas telpon ke desa berpengaruh secara statistik terhadap keputusan bermigrasi.

Berkenaan dengan keputusan bermigrasi, Lam (2001) memadukan interaksi faktor ekonomi dan politik dalam mengambil keputusan bermigrasi. Dijelaskan oleh Lam, bahwa lemahnya sistem politik meningkatkan secara signifikan kecenderungan bermigrasi. Begitu juga, dengan melemahnya sistem ekonomi akan terjadi peningkatan bermigrasi walaupun cenderung relatif kecil. Sedangkan penelitian Mahmood (2002) dengan menggunakan 1500 sarjana di Pakistan sebagai responden menyebutkan bahwa faktor-faktor ekonomi seperti: posisi karir yang lebih tinggi; pendapatan yang tinggi; dan standar hidup yang lebih baik, cenderung signifikan dari pada faktor-faktor sosialpolitik dan institusional, seperti: ijin tinggal; toleransi rasial; bahasa atau kultur; dan jaringan sosial.

Waridin (2002) dan Susilowati (1998) mengemukakan hasil studinya tentang beberapa faktor yang mempengaruhi migrasi TKI ke luar negeri, di antaranya adalah: faktor sosial, ekonomi, dan politik. Para TKI yang berusia muda dan berpendidikan relatif tinggi cenderung untuk tidak menetap secara permanen. Sedangkan faktor lain yang diduga mempengaruhi niat migrasi responden dalam bekerja di luar negeri secara statistik tidak dapat menjelaskan bagaimana fenomena dari niat TKI responden untuk bekerja dan menetap di luar negeri.

Djamba (1999) menyatakan dalam penelitiannya, bahwa di Vietnam gerakan mobilitas tidak dibatasi oleh kebijakan pemerintah. Menurutnya, faktor-faktor kontekstual di luar kebijakan pemerintah dianggap penting dalam menentukan siapa yang pindah dan menentukan hasil mobilitas. Dijelaskan pula oleh Djamba (1999), bahwa kota-kota di Vietnam dianggap sangat menimbulkan daya pikat sebagai tempat tujuan bagi para migran temporer, baik yang bekerja di bidang perdagangan maupun di bidang jasa.

Berdasarkan hasil penelitian Yeremias (1994) tentang niat bermigrasi disimpulkan bahwa: satu, migran yang datang ke kota tidak selalu berniat untuk menetap di kota. Terdapat migran yang berniat pulang ke desa, sementara ada yang ragu-ragu atau tidak dapat mengambil keputusan. Kedua, niat tersebut ditentukan oleh faktor-faktor place utility, latar belakang individu, dan latar belakang struktural. Ketiga, model plece utility bermanfaat dan relevan dalam menjelaskan niat bermigrasi di Indonesia.

\section{METODE PENELITIAN}

Penelitian ini merupakan pengembangan dari penelitian yang sebelumnya telah dilakukan, yaitu mengenai pola migrasi dari para migran. Lokasi penelitian masih sama dengan penelitian terdahulu, hanya tujuan para migran yang dikembangkan yaitu tidak hanya satu tujuan tetapi beberapa kota tujuan migran. Pendekatan penelitian ini menggunakan metode survey lapangan untuk mengetahui kondidi kantong para migran. Penelitian diarahkan untuk menjawab tujuan penelitian 
(a) yaitu untuk menganalisa bagaimana kondisi tenaga kerja di daerah Kabupaten Wonogiri; dan (b) yaitu untuk menganalisa dampak migrasi terhadap tingkat kesejahteraan di daerah Kabupaten Wonogiri.

\section{Metode Pengumpulan Data}

Penelitian ini diawali dengan pra penelitian yaitu dengan suvei awal untuk mendapatkan informasi tentang perkembangan aktivitas migrasi di daerah penelitian (kondisi pasca penelitan terdahulu). Selanjutnya aktivitas yang berkaitan dengan perijinan (oleh tim peneliti) dari instansi atau dinas yang terkait. Populasi dan sampel penelitian ditentukan berdasar wilayah yang mempunyai karakteristik kantong migran. Kegiatan penelitian di lapangan, yaitu akan melakukan survei di obyek penelitian untuk mendapatkan data dari para responden, yaitu difokuskan pada kantong-kantong migran.

\section{Analisis Data}

Analisis data dilakukan baik secara kualitatif dan kuantitatif. Untuk memprediksi dan membandingkan pola migrasi dari para migran berdasar keniatan migran ke masingmasing kota tujuan, digunakan pendekatan analisis kuantitatif dengan model logistik (Gujarati, 1995; Greene, 2000; Maddala, 1992). Pengunaan model regresi Logit ini dianggap sebagai alat yang tepat untuk menganalisa data dalam penelitian ini karena dependen variabel disini bersifat dikotomi atau multinomial, yaitu lebih dari satu atribut (Hossain, 2001). Selain itu juga digunakan analisis regresi linier untuk mendapatkan analisis ekonomi terkait dengan fenomena pendapatan migran.

Sedangkan untuk mendapatkan gambaran karakteristik dan mengakomodasi perma- salahan para migran, baik di desa asal maupun di kota tujuan, dilakukan pendekatan kelompok (analisis diskriptif), yaitu datang pada daerah asal responden, bertemu dengan perwakilan responden (pendekatan dengan ketua desa setempat). Hasil pendekatan atau penelusuran ini digunakan untuk menjelaskan secara diskriptif mengapa mereka meninggalkan desa asal dan melakukan migrasi.

\section{HASIL PENELITIAN DAN PEMBAHASAN}

\section{Analisis Binary Logit}

Untuk memprediksi dan membandingkan pola migrasi dari para perantau berdasar keniatan perantau ke masing-masing kota tujuan, digunakan pendekatan analisis kuantitatif dengan model logistik (Gujarati, 1995; Greene, 2000; Maddala, 1992; Susilowati, 1998; Keban, 1994). Pengunaan model regresi Logit ini dianggap sebagai alat yang tepat untuk menganalisa data dalam penelitian ini karena dependen variabel disini bersifat dikotomi atau multinomial, yaitu lebih dari satu atribut (Hossain, 2001). Hipotesis yang digunakan dalam penelitian ini adalah niat perantau untuk menentap di daerah rantauan dipengaruhi oleh umur (AGE), pendidikan (EDUC), pendapatan (INCM), status pernikahan (MARIED), kepemilikan harta di daerah asal (ASET), pekerjaan di daerah asal (JOB VELG).Selain analisa logit juga digunakan analisis regresi linier berganda untuk mengetahui faktorfaktor yang mempengaruhi pendapatan perantau. Hasil dari pengujian hipotesis tersebut untuk menjawab tujuan penelitian ini, yaitu menganalisis faktor-faktor yang 
mempengaruhi niat penduduk Wonogiri untuk menetap di perantauan.

Untuk membuktikan hipotesis di atas maka telah dilakukan estimasi model regresi logistik sebagai berikut:

NIAT $=\mathrm{f}($ AGE, EDUC, INCM, MARIED, ASET, JOB VELG)

dimana:

NIAT $=0$, bila berniat untuk menetap; 1 , bila tidak berniat untuk menetap;

$\mathrm{AGE}=$ umur;

$\mathrm{EDUC}=$ pendidikan;

$\mathrm{INCM}=$ pendapatan;

MARIED = status pernikahan;

ASET $=$ kepemilikan harta di daerah asal; JOB VELG = pekerjaan di daerah asal.

Hasil analisis menunjukkan bahwa ada 3 variabel independen yang digunakan tidak memiliki pengaruh yang signifikan terhadap niat perantau untuk menetap di daerah rantauan, yaitu: Pendapatan (INCM); Kepemilikan Harta di daerah asal (ASET); Pekerjaan di daerah asal (JOB_VELG) dan ada 3 variabel independen yaitu umur (AGE), pendidikan (EDUC), status pernikahan (MARIED), yang berpengaruh signifikan pada $\alpha=5 \%$ terhadap niat perantau untuk menetap di daerah rantauan. Ketiadaan pengaruh yang signifikan antara Pendapatan (INCM); Kepemilikan Harta di daerah asal (ASET); Pekerjaan di daerah asal (JOB_VELG) terhadap niat menetap perantau disebabkan oleh kondisi lingkungan para perantau yang berbeda-beda, sehingga perbedaan tersebut mengakibatkan ketiadaan pengaruh terhadap niat untuk menetap. Sedangkan percentage of right prediction nya adalah 81,6 persen. Secara rinci ringkasan hasil estimasi skenario ini dapat dilihat pada Tabel 2.

Temuan di lapangan menjelaskan bahwa umur (AGE), pendidikan (EDUC), status pernikahan (MARIED), kepemilikan harta di daerah asal (ASET), pekerjaan di daerah asal (JOB VELG) memiliki hubungan negatif terhadap niat perantau untuk menetap di daerah rantauan. Hal ini sesuai dengan hipotesa yang diajukan, karena para perantau hanya ingin bekerja di derah rantauan dengan tujuan untuk meningkatkan taraf hidup keluarganya dan meningkatkan perekonomian keluarganya, setelah mereka tua akan kembali kedesanya untuk menikmati hari tuanya di daerah asal karena 88,8 persen perantau memiliki aset di daerah asalnya sehingga di hari tua mereka akan kembali didaerahnya.

Sedangkan pendapatan (INCM) memiliki pengaruh positif terhadap niat perantau untuk menetap di daerah rantauan. Hal ini sesuai dengan hipotesis yang diajukan, karena para perantau hanya ingin bekerja di derah rantauan dengan pendapatan yang lebih tunggi dibandingkan dengan daerah asal. Selisih pendapatan tersebut mendorong perantau untuk lebih lama untuk menetap di daerah perantauan.

Bedasarkan temuan di lapangan dan analisis data terdapat 4,8 persen perantau yang berniat untuk menetap di perantauan jadi menetap dan 15,6 persen perantau yang tidak berniat untuk menetap di perantauan jadi tidak menetap. Probabilitas kejadian kondisi tersebut sebesar 0,235. Sedangkan perantau yang berniat untuk menetap di perantauan jadi menetap sebesar 2,8 persen dan perantau yang tidak berniat untuk menetap di perantauan jadi tidak menetap 
Tabel 2. Nilai Koefisien Regresi Logistik

\begin{tabular}{|c|c|c|c|}
\hline Variabel & Koefisien & Wald-ratio & $\begin{array}{c}\text { Sig. } \\
\text { (p-value) }\end{array}$ \\
\hline AGE & -.341 & 25.972 & $.000^{*}$ \\
\hline EDCATION & -.062 & 7.397 & $.007^{*}$ \\
\hline INCM & 1.166 & 4.866 & $.027^{\star *}$ \\
\hline MERIED & -.362 & .353 & .553 \\
\hline ASET & -.463 & .644 & .422 \\
\hline JOP_VELG & -.061 & .410 & .522 \\
\hline Constant & 6.741 & 26.678 & $.000 *$ \\
\hline \multicolumn{4}{|l|}{ Chi-Square (Hosmer and } \\
\hline \multirow{2}{*}{ Observed } & \multicolumn{3}{|c|}{$\begin{array}{c}8,816(p-v a l u e=0.358) \\
\text { Predicted }\end{array}$} \\
\hline & Menetap & Tidak Menetap & $\%$ Correct \\
\hline$(0=$ Menetap $)$ Niat ; & 12 & 39 & 23,5 \\
\hline (1= Tidak Menetap) & 7 & 192 & 96,0 \\
\hline Overall \% & & & 81,2 \\
\hline
\end{tabular}

sebesar 76,8 persen. Probabilitas kejadian kondisi tersebut sebesar 0,235. Sehingga secara keseluruhan model regresi logit yang dipakai untuk menerangkan faktor-faktor yang mempengaruhi niat perantau untuk menetap di daerah rantauan mempunyai kehandalan dalam memprediksi sebesar 81,6 persen.

Kenyataan ini diperkuat dengan data di lapangan ketika dilakukan survei, yaitu sebagian besar perantau menyatakan keinginannya untuk tidak menetap di daerah rantauan. Berdasarkan temuan survei di lapangan terdapat sebanyak 88,8 persen perantau dari Wonogiri tidak berkeinginan untuk menetap di daerah rantauan.

\section{Analisis Regresi Linier}

Hasil analisis menunjukkan bahwa hanya ada 1 variabel independen yang digunakan memiliki pengaruh yang signifikan terhadap pendapatan perantau di daerah rantauan, yaitu: tingkat pendidikan (EDUC) sedangkan variabel independent lainnya yaitu tanggungan keluarga (RES); Kepemilikan Harta di daerah asal (ASET); lama di perantauan (LONG_JOB) dan status perkawinan (MARIED), tidak memiliki pengaruh yang signifikan pada $\alpha=5 \%$. Secara rinci ringkasan hasil estimasi ini dapat dilihat pada tabel 3.

Tanggungan keluarga tidak memiliki pengaruh yang signifikan terhadap pendapatan perantau karena sebagian tanggungan keluarga ditanggung oleh mereka yang di daerah. Selain itu selisih biaya hidup antara daerah rantauan dengan daerah asal menyebabkan berkurangnya beban tanggungan yang harus perantau pikul. Sedangkan kepemilikan harta juga tidak berpengaruh secara signifikan terhadap pendapatan perantau karena aset yang dimiliki perantau di daerah 
Tabel 3. Nilai Koefisien Regresi Linear

Coefficients

\begin{tabular}{|c|c|c|c|c|c|c|c|c|}
\hline & \multirow[b]{2}{*}{ Model } & \multicolumn{2}{|c|}{$\begin{array}{l}\text { Unstandardized } \\
\text { Coefficients }\end{array}$} & \multirow{2}{*}{$\begin{array}{c}\begin{array}{c}\text { Standardized } \\
\text { Coefficients }\end{array} \\
\text { Beta }\end{array}$} & \multirow[b]{2}{*}{$t$} & \multirow[b]{2}{*}{ Sig. } & \multicolumn{2}{|c|}{ Collinearity Statistics } \\
\hline & & B & $\begin{array}{l}\text { Std. } \\
\text { Error }\end{array}$ & & & & Tolerance & VIF \\
\hline \multirow[t]{6}{*}{1} & (Constant) & .144 & .642 & & .225 & .822 & & \\
\hline & EDUC & .119 & .042 & .201 & 2.854 & .005 & .789 & 1.267 \\
\hline & AGE & .015 & .016 & .090 & .938 & .349 & .423 & 2.363 \\
\hline & MARIED & -.018 & .371 & -.004 & -.047 & .962 & .563 & 1.775 \\
\hline & RES & .079 & .052 & .109 & 1.526 & .128 & .764 & 1.309 \\
\hline & LOG_JOE & .012 & .016 & .062 & .726 & .469 & .534 & 1.874 \\
\hline
\end{tabular}

a. Dependent Variable: INCM

tidak membebani secara langsung oleh perantau, sehingga keadaan tersebut tidak mendorong perantau untuk lebih meningkatkan pendapatannya. Lama bekerja juga tidak memiliki pengaruh yang signifikan terhadap pendapatan perantau karena lebih dari 85 persen perantau bekerja pada sektor informal sehingga lama bekerja tidak memiliki pengaruh yang signifikan. Status perkawinan juga tidak berpengaruh terhadap pendapatan perantau karena istri atau suami bukan menadi beban namun justru sebagai pengurang beban, karena mereka juga bekerja sehingga secara bersama-sama akan meningkatkan pendapatan perantau.

\section{Analisis Deskriptif}

Dari gambar 1 terlihat bahwa 20,4 persen perantau berniat untuk menetap di daerah tujuan mereka bekerja dan 79,6 persen perantau tidak berniat untuk menetap di daerah tujuan mereka bekerja. Kondisi tersebut menunjukkan bahwa mereka merantau hanya untuk bekerja guna mendapatkan pendapatan yang nantinya akan digunakan untuk meningkatkan kesejahteraan mereka dan keluarganya yang ada di daerah. Selain itu kondisi tepat mereka bekerja tidak memungkinkan mereka untuk menetap di perantauan karena tanah yang mahal dan mereka juga masih memiliki harta benda

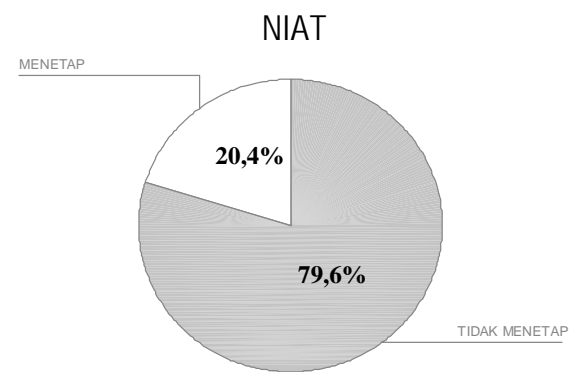

Gambar 1. Prosentase Niat Perantau untuk Menetap di Daerah Perantauan dari Daerah Wonogiri 
yang ada di daerah asalnya.

Dari gambar 2 terlihat bahwa 2,4 persen perantau berpendidikan sarjana, 2,4 persen berpendidikan sarjana muda, 22,8 persen berpendidikan SMA, 21,2 persen berpendidikan SMP dan 50,2 persen adalah berpendidikan SD. Fenomena ini menunjukkan bahwa tingkat pendidikan perantau dari daerah Wonogiri masih sangat rendah karena didominasi pendidikan SD. Kondisi tersebut menunjukkan bahwa mereka yang merantau banyak yang bekerja pada sektor informal misalkan pedagang bakso, pedagang jamu gendong dan buruh kasar.

Dari gambar 3 terlihat bahwa 1,8 persen perantau berumur lebih dari 60 tahun, 10 persen perantau berumur antara 51 sampai 60 tahun, 26,4 persen perantau berumur antara 41 sampai 50 tahun, 31,6 persen perantau berumur antara 31 samapai 40 tahun, 26,4 persen perantau berumur antara 21 sampai 30 tahun, dan 4,8 persen perantau berumur kurang dari 20 tahun. Fenomena yang dapat di tangkap dari kondisi ini adalah terjadi trend yang meningkat keinginan untuk bekerja di perantauan ketika umur produktif yaitu 18 sampai 40 tahun. Kemudian akan mengalami penurunan keinginan untuk bekerja di rantau ketika berumur lebih dari 40 tahun. Kondisi demikian dapat memperlihatkan bahwa minat untuk menetap di daerah rantauan dari perantau akan menurun, sehingga secara umum mereka enggan untuk menetap di daerah rantauan. Ketika umur mereka mulai usur maka mereka akan pulang kedaerahnya untuk menikmati hasil selama meraka bekerja diperantauan dan bekerja seadanya di daerah asal.

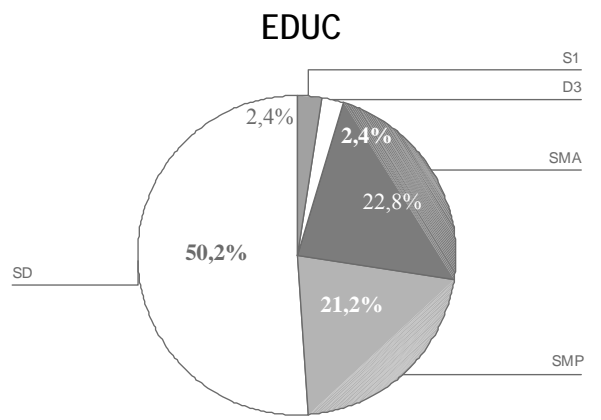

Gambar 2. Prosentase Tingkat Pendidikan Perantau dari Daerah Wonogiri

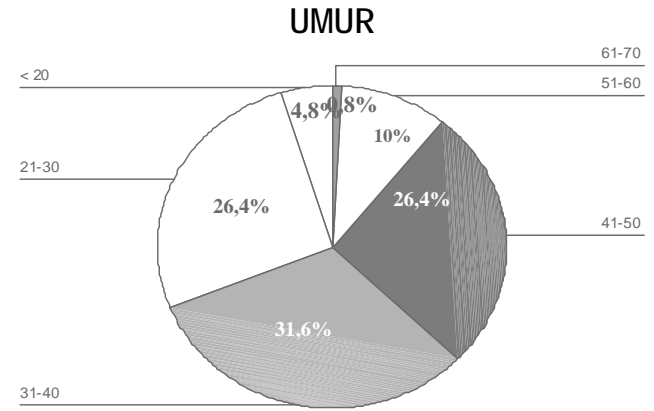

Gambar 3. Prosentase Tingkat Umur Perantau dari Daerah Wonogiri 
MARIED

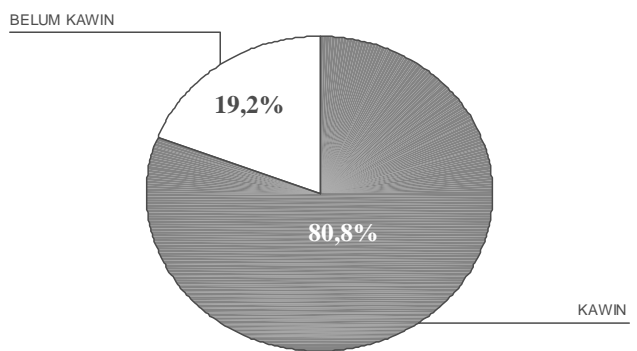

\section{Gambar 4. Persentase Status Perkawinan Perantau dari Daerah Wonogiri}

Dari gambar 4 terlihat bahwa 19,2 persen perantau belum menikah dan 80,8 persen perantau sudah pernah menikah. Kondisi tersebut menunjukkan bahwa mereka merantau hanya untuk bekerja guna mendapatkan pendapatan yang nantinya akan digunakan untuk meningkatkan kesejahteraan mereka dan keluarganya yang ada di daerah. Setelah mereka memiliki pendapatan meraka akan menikah. Ketika mereka menikah kebanyakan mencari pasangan dari daerah asal, sehingga minat untuk menetap di daerah rantauan akan semakin berkurang.

Dari gambar 5 terlihat bahwa 10,8 persen perantau tidak memiliki harta benda di daerah asalnya dan 89,2 persen perantau memiliki harta benda di daerah asalnya. Kondisi tersebut menunjukkan bahwa mereka merantau untuk bekerja mendapatkan uang kemudian mereka belanjakan di daerah asal untuk meningkatkan kesejahteraan keluarganya yang ada di daerah.

Dari gambar 6 terlihat bahwa 0,4 persen perantau memiliki jumlah tanggungan keluarga yang ada di daerah asal maupun di perantauan 12 orang. Tanggungan dalam hal ini termasuk mereka yang sedang sekolah yang ada di perantauan dan di daerah asal. 3,6 persen perantau memiliki jumlah tanggungan keluarga yang ada di daerah asal maupun di perantauan 10 orang, 0,8 persen perantauan memiliki jumlah tanggungan keluarga yang ada di daerah asal maupun di perantauan 9 orang. 0,8 persen perantauan memiliki jumlah tanggungan keluarga yang ada di daerah asal maupun di perantauan 8 orang. 11,6 persen perantauan memiliki jumlah tanggungan keluarga yang ada di daerah asal maupun di perantauan 7 orang. 18 persen perantauan memiliki jumlah tanggungan keluarga yang ada di daerah asal maupun di perantauan 6 orang. Namun secara rata-rata jumlah tanggungan para perantau yang ada di perantauan dan daerah asal adalah 4 orang. Kondisi tersebut menunjukkan bahwa tanggungan keluarga yang harus mereka tanggung cukup berat karena rata-rata orang yang harus di tanggung oleh perantau di perantauan sebanyak 4 orang.

Dari gambar 7 terlihat bahwa 1,2 persen perantau tidak memiliki pekerjaan di daerah sebelum dan sesudah mereka merantau dan 85,6 persen perantau memiliki pekerjaan di daerah sebelum dan sesudah mereka merantau, siasanya tidak menjawab. Fenomena ini dapat memperlihatkan bahwa minat untuk menetap di daerah rantauan dari perantau akan menurun, sehingga kepemilikan pekerjaan di daerah asal akan mempengaruhi niat untuk mereka enggan untuk menetap di 


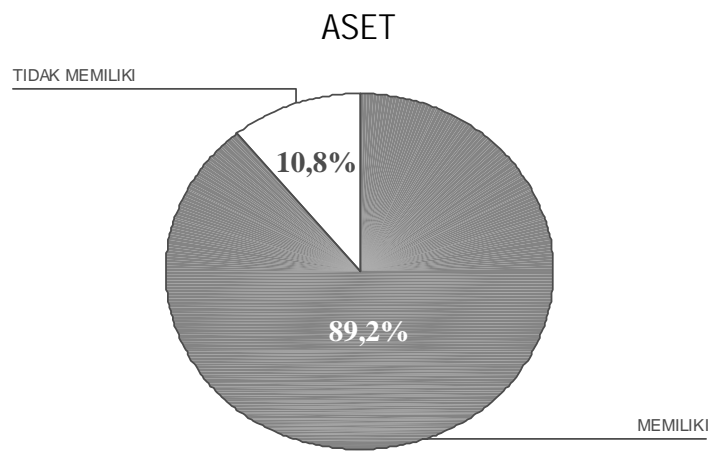

\section{Gambar 5. Prosentase Kepemilikan Harta Benda di Daerah Asal Perantau dari Daerah Wonogiri}

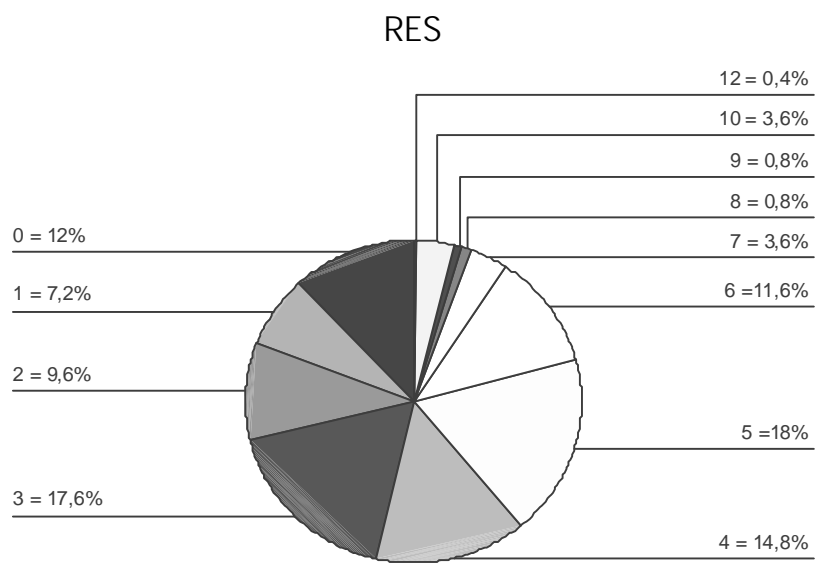

\section{Gambar 6. Prosentase Jumlah Tanggungan Perantau dari Daerah Wonogiri}

daerah rantauan. Ketika mereka memiliki pekerjaan di daerah asal maka mereka akan pulang ke daerahnya untuk menikmati hasil selama meraka bekerja di perantauan dan bekerja seadanya di daerah asal.

Dari gambar 8 terlihat bahwa 30,4 persen perantau memiliki masa kerja kurang dari lima tahun, sedangkan 28 persen perantau memiliki masa kerja antara enam sampai 10 tahun, dan 8,4 persen perantau memiliki masa kerja lebih dari dua puluh lima tahun. Namun secara rata-rata lama bekerja para perantau yang ada di perantauan adalah 11,9 tahun. Kondisi tersebut menunjukkan bahwa para perantau sudah lama melakukan kegiatannya, sehingga lama bekerja tidak memiliki pengaruh yang signifikan terhadap pendapatan dan niat menetap di daerah perantauan, karena lamanya mereka bekerja justru membuat mereka jenuh dan akhirnya mereka akan kembali ke daerah asal.

Dari gambar 9 terlihat bahwa 10,4 persen perantau memiliki pendapatan kurang dari satu juta perbulan, sedangkan 64,8 


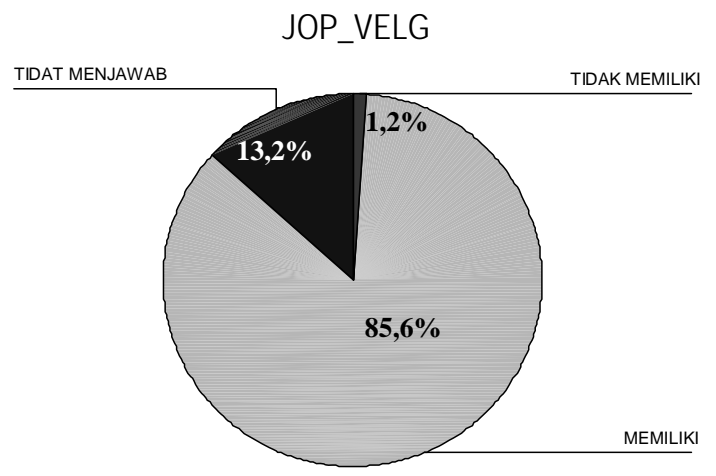

\section{Gambar 7. Prosentase Pekerjaan di Daerah Asal Perantau dari Daerah Wonogiri}

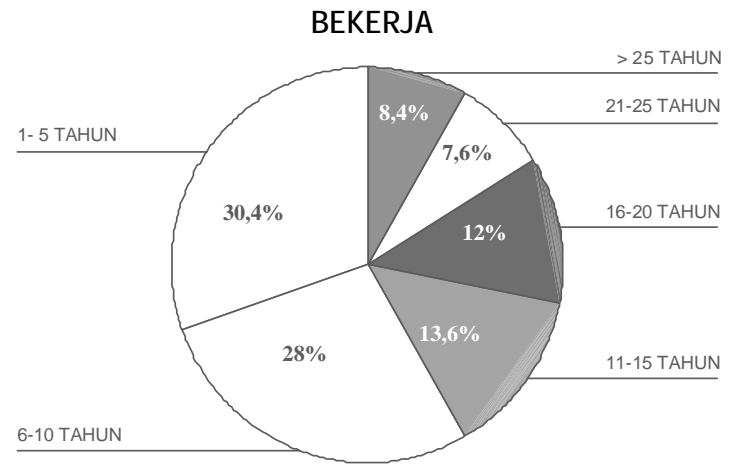

\section{Gambar 8. Prosentase Lama Bekerja Perantau dari Daerah Wonogiri}

persen perantau memiliki pendapatan antara satu juta hingga dua juta rupiah, dan 24,8 , persen perantau memiliki pendapatan lebih dari dua juta rupiah. Kondisi tersebut menunjukkan bahwa para perantau sudah cukup layak hidupnya, selain mereka dapat hidup di rantau, mereka juga dapat menghidupi keluarganya yang di daerah asal dengan layak pula, sehingga pendapatan perantau tidak memiliki pengaruh yang signifikan terhadap niat menetap di daerah perantauan.

Dari gambar 10 terlihat bahwa 85,4 persen kepemilikan harta perantau mengalami perubahan yang meningkat sedangkan 15,6 persen kepemilikan harta perantau mengalami perubahan yang menurun. Ada- nya perubahan yang meningkat sebagai akibat dari meningkatnya pendapatan dari perantau di daerah rantauan. Sedangkan penurunan kepemilikan harta perantau sebagai akibat dari penjualan untuk pembiayaan kuliah atau untuk meningkatkan usahanya.

Dari gambar 11 terlihat bahwa 30,4 persen pengurangan harta perantau untuk pembiayaan kuliah, 22,4 persen pengurangan harta untuk pembiayaan SMA, 47,2 persen penguranggan harta untuk pembiayaan Sekolah Dasar. Sedangkan penurunan kepemilikan harta perantau sebagai akibat dari penjualan untuk pembiayan sekolah atau untuk meningkatkan usahanya. 


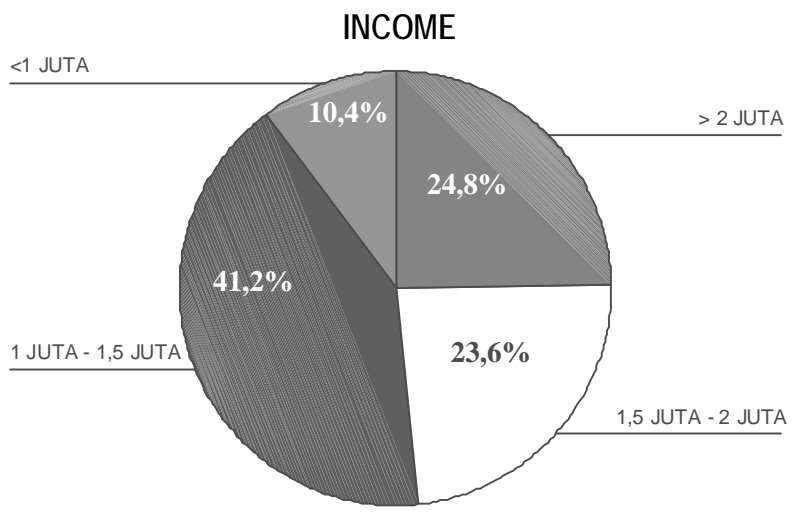

Gambar 9. Prosentase Tingkat Pendapatan Perantau dari Daerah Wonogiri

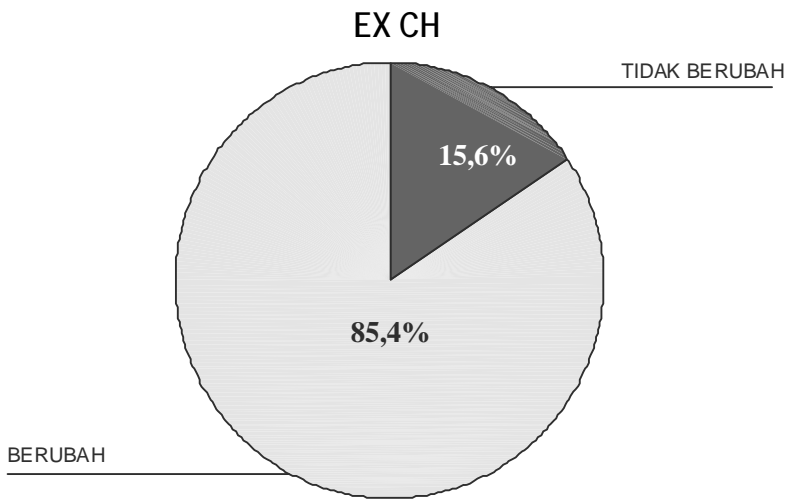

\section{Gambar 10. Prosentase Tingkat Perubahan Kepemilikan Kekayaan Sebelum dan Sesudah Boro Perantau dari Daerah Wonogiri}

Dari gambar 12 terlihat bahwa 49,6 persen para perantau mengirim uang lewat transfer dan 34,8 persen melalui titip terhadap temannya. Kondisi ini memperlihatkan bahwa terjadi perubahan karakteristik perantau. Dahulu mereka jika menggirim uang melalui titip pada temannya atau langsung pulang. Fenomena ini juga memperlihatkan bahwa para perantau sudah bisa memanfaatkan fasilitas guna kemudahan mereka dan dengan semakin cepatnya pengiriman uang ke daerah asal maka semakin cepat pula perubahan yang akan terjadi di daerah asal. Rata-rata para perantau dalam mengirimkan uang dalam satu tahun adalah 12 kali. Fenomena ini dapat diartikan bahwa para perantau setiap bulannya mampu menyimpan uang untuk dikirimkan ke daerah asal. 


\section{EXE DUC}

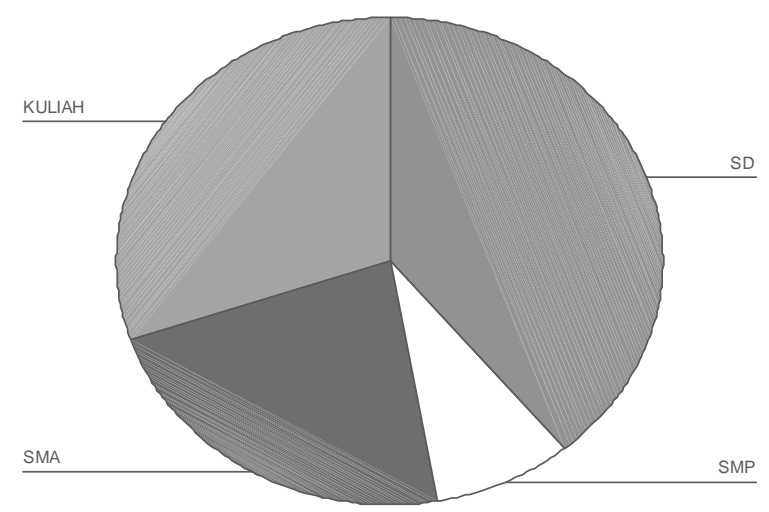

\section{Gambar 11. Prosentase Tingkat Perubahan Kepemilikan Beban Sekolah Sebelum dan Sesudah Boro Perantau dari Daerah Wonogiri}

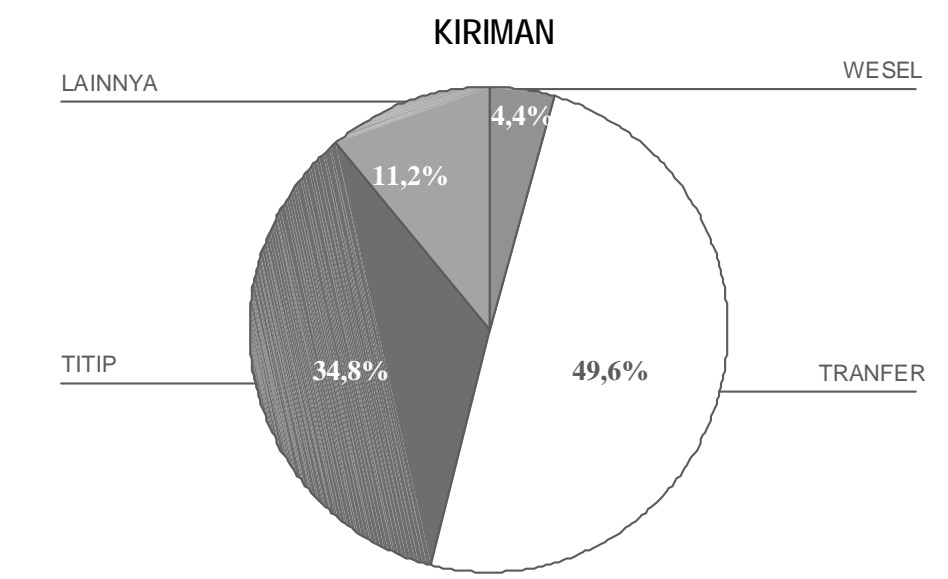

Gambar 12. Prosentase Jumlah Kiriman Perantau dari Daerah Wonogiri

\section{KESIMPULAN}

Hasil analisis menunjukkan bahwa ada 3 variabel independen yang digunakan tidak memiliki pengaruh yang signifikan terhadap niat perantau untuk menetap di daerah rantauan, yaitu: Pendapatan (INCM); Kepemilikan Harta di daerah asal (ASET); Pekerjaan di daerah asal (JOB_VELG) dan ada 3 variabel independen yaitu umur (AGE), pendidikan (EDUC), status pernikah- an (MARIED), yang berpengaruh signifikan pada $\alpha=5 \%$ terhadap niat perantau untuk menetap di daerah rantauan. Ketiadaan pengaruh yang signifikan antara Pendapatan (INCM); Kepemilikan Harta di daerah asal (ASET); Pekerjaan di daerah asal (JOB_VELG) terhadap niat menetap perantau disebabkan oleh kondisi lingkungan para perantau yang berbeda-beda, sehingga perbedaan tersebut mengakibatkan ketiadaan pengaruh terhadap niat untuk menetap. 
Sedangkan percentage of right prediction nya adalah 81,6 persen.

Hasil analisis ekonomi menunjukkan bahwa hanya ada 1 variabel independen yang digunakan memiliki pengaruh yang signifikan terhadap pendapatan perantau di daerah rantauan, yaitu: tingkat pendidikan (EDUC) sedangkan variabel independent lainnya yaitu tanggungan keluarga (RES); Kepemilikan Harta di daerah asal (ASET); lama di perantauan (LONG_JOB) dan status perkawinan (MARIED), tidak memiliki pengaruh yang signifikan pada $\alpha=5 \%$.

Hasil survei di lapangan memperlihatkan bahwa 2,4 persen perantau berpendidikan sarjana, 2,4 persen berpendidikan sarjana muda, 22,8 persen berpendidikan SMA, 21,2 persen berpendidikan SMP dan 50,2 persen adalah berpendidikan SD. Fenomena ini menunjukkan bahwa tingkat pendidikan perantau dari daerah Wonogiri masih sangat rendah karena didominasi pendidikan SD. Kondisi tersebut menunjukkan bahwa mereka yang merantau banyak yang bekerja pada sektor informal misalkan pedagang bakso, pedagang jamu gendong dan buruh kasar.

Berdasar aset atau harta yang dimiliki para perantau, 10,8 persen perantau tidak memiliki harta benda di daerah asalnya dan 89,2 persen perantau memiliki harta benda di daerah asalnya. Kondisi tersebut menunjukkan bahwa mereka merantau untuk bekerja mendapatkan uang kemudian meraka belanjakan di derah asal untuk meningkatkan kesejahteraan keluarganya yang ada di daerah.

Dan dari sisi jumlah tanggungan keluarga tercermin 0,4 persen perantau memiliki jumlah tanggungan keluarga yang ada di daerah asal maupun di perantauan 12 orang.
Tanggungan dalam hal ini termasuk mereka yang sedang sekolah yang ada di perantauan dan di daerah asal. 3,6 persen perantau memiliki jumlah tanggungan keluarga yang ada di daerah asal maupun di perantauan 10 orang, 0,8 persen perantauan memiliki jumlah tanggungan keluarga yang ada di daerah asal maupun di perantauan 9 orang. 0,8 persen perantauan memiliki jumlah tanggungan keluarga yang ada di daerah asal maupun di perantauan 8 orang. 11,6 persen perantauan memiliki jumlah tanggungan keluarga yang ada di daerah asal maupun di perantauan 7 orang. 18 persen perantauan memiliki jumlah tanggungan keluarga yang ada di daerah asal maupun di perantauan 6 orang. Namun secara rata-rata jumlah tanggungan para perantau yang ada di perantauan dan daerah asal adalah 4 orang. Kondisi tersebut menunjukkan bahwa tanggungan keluarga yang harus mereka tanggung cukup berat karena rata-rata orang yang harus di tanggung oleh perantau di perantauan sebanyak 4 orang.

Peran para perantau juga dapat terlihat dari fenomena perubahan keadaan ekonomi di desa asalnya, seperti yang terlihat bahwa 85,4 persen kepemilikan harta perantau mengalami perubahan yang meningkat sedangkan 15,6 persen kepemilikan harta perantau mengalami perubahan yang menurun. Adanya perubahan yang meningkat sebagai akibat dari meningkatnya pendapatan dari perantau di daerah rantauan. Sedangkan penurunan kepemilikan harta perantau sebagai akibat dari penjualan untuk pembiayaan kuliah atau untuk meningkatkan usahanya.

Berdasarkan hasil perhitungan analisis penelitian tentang Migrasi Tenaga Kerja dan Perannya Bagi Pembangunan Daerah Asal, dapatlah diberi saran-saran sebagai berikut: 
Hasil penelitian di atas menunjukkan kecenderungan migran asal Wonogiri tetap sebagai migran sirkuler (temporary), dengan demikian para tenaga kerja asal Wonogiri ini akan lebih suka tetap tinggal di desa asalnya bila tersedia lapangan pekerjaan atau lahan yang dapat digarap. Hal ini memberikan konsekuensi kepada pemerintah dalam hal ini Pemda Kabupaten Wonogiri untuk dapat menyediakan/menciptakan lapangan pekerjaan, termasuk penyediaan lahan garapan yang tidak produktif menjadi lahan produktif. Adanya lahan garapan bagi para migran di Wonogiri ini sesuai dengan keinginan mereka untuk tetap bekerja di daerah asalnya.

Migran yang berniat menetap, biasanya adalah mereka yang sudah mapan dalam pekerjaan dan penghasilannya. Mereka akan memberikan informasi kepada migran potensial di desa asal (Wonogiri). Untuk itu, disarankan, Pemda Wonogiri perlu mengkoordinir para migran ini dengan bekerjasama dengan paguyuban yang telah ada. Hal ini dapat diwujudkan, apabila dilakukan pendataan mengenai tenaga kerja yang melakukan aktivitas boro. Upaya pendataan ini, selain bermanfaat dari sisi administrasi, juga sebagai indikator untuk mengontrol mobilitas penduduk.

Berdasar pengamatan di lapangan, fenomena para perantau asal Wonogiri ini semakin meningkat setiap tahunnya. Sehingga, dampak dari mobilitas penduduk ini terlihat pada peningkatan prasarana dan kemudahan transportasi, yang selanjutnya menjadi penghubung antara kehidupan desa dengan kota, dimana banyak tenaga kerja asal Wonogiri berharap meningkatkan kesejahteraannya di daerah tujuan. Pemerintah dalam hal ini Pemda Kabupaten
Wonogiri tidak dapat mencegah fenomena ini, tetapi yang diperlukan justru dukungan terhadap mereka, paling tidak dalam bentuk moril.

\section{DAFTAR PUSTAKA}

Djamba, Y, Alice and Sidney. 1999. Permanent and Temporary Migration in Vietnam during a period of Economic Change, Asia-pasific Population Journal, Vol.14, No.3, September 1999.

Firman, T. 1994., Migrasi Antar Provinsi dan Pengembangan Wilayah di Indonesia, Jurnal Prisma No. 7 Juli 1994.

Frederickson 1992. Permanent versus Temporary Rural Migrants in Riyadh, a Logit Analysis of Their Intentions of Future Mobility, GeoJournal, 26 (3).

Greene, W.H. 2000. Econometric Analysis, fourth edition, International Edition, NY, Prentice Hall International, Inc.

Gujarati, D. 1998. Basic Econometrics, $3^{\text {rd }}$ edition, International Edition, Singapore: McGraw-Hill.

Keban, Y.T. 1994. Studi Niat Bermigrasi di Tiga Kota: Determinan dan Intervensi Kebijaksanaan, Jurnal Prisma No.7 Juli 1994.

Kennan, J and James Walker. 2002. The Effect of Expected Income on Individual Migration Decisions, Preliminary and Incomplete, University of WisconsinMadison and NBER, July 2002.

Lam, Kit-Chun. 2001. Interaction Between Economic and Political Factors In the MigrationDecision,www.hiebs.hku.hk/ working_papers_updates/pdf/wp1028.p df. 
Lee, E.S. 1992. Teori Migrasi (Terjemahan), Pusat Penelitian Kependudukan Universitas Gajah Mada.

Mantra, I.B. 1992. Mobilitas Penduduk Sirkuler Dari Desa ke Kota di Indonesia, Pusat Penelitian Kependudukan Universitas Gajah Mada.

Mantra, I.B. 2000. Demografi Umum. Pustaka Pelajar, Yogyakarta.

Oishi, N. 2002. Gender and Migration: An Integrative Approach, Working Paper No. 49 March, 2002.

Purwadi. 1995. Analisa Terhadap Faktorfaktor yang Mempengaruhi Pendapatan Migran Sirkuler: Kasus Migran Sirkuler Asal Wonogiri di Jakarta, Hasil Riset Non-Publikasi, FE UNS.

Saefullah, A. D. 1994. Mobilitas Penduduk dan Perubahan di Pedesaan, Jurnal Prisma No.7 Juli 1994.

Soepono, P. 1995. Studies On Interprovincial Migration in Indonesia: The Current Status, Jurnal Kelola No. 3/IV/1995.

Susilowati, I. 1998. Analisis Masalah Sosial, Politik dan Ekonomi pada Migrasi Tenaga Kerja Indonesia ke Luar Negeri, Hasil Riset URGE Non-Publikasi, Fakultas Ekonomi UNDIP, 1998.

Titus, Milan J. 1991. Regional and Rural Development Planning, Faculty of Geography UGM.

Todaro, M.P. 1992. Kajian Ekonomi Migrasi Internal di Negera Berkembang (terjemahan), Pusat Penelitian Kependudukan Universitas Gajah Mada.

Waridin. 2002. Beberapa Faktor yang Mempengaruhi Migrasi Tenaga Kerja Indonesia (TKI) ke Luar Negeri, Jurnal
Ekonomi Pembangunan (JEP) Vol.3 No.2 Desember 2002.

Yang, Xiushi. 1992. Temporary Migration and Its Frequency from Urban Households in China, Asia-Paciic population Journal, Vol.7 No.1, 1992, p. 27 - 50. 